\title{
Assessment of Water Pollution in Different Aquatic Systems: Aquifers, Aquatic Farms on the Jamapa River, and Coastal Lagoons of Mexico
}

\author{
Cesáreo Landeros-Sánchez ${ }^{1}$, Fabiola Lango-Reynoso², María del Refugio Castañeda-Chávez ${ }^{2}$, Itzel \\ Galaviz-Villa $^{2}$, Iourii Nikolskii-Gavrilov ${ }^{1}$, Martín Palomarez-García ${ }^{1}$, Christian Reyes-Velázquez ${ }^{1} \&$ Martha \\ Magaly Mínguez-Rodríguez ${ }^{2}$ \\ ${ }^{1}$ Colegio de Postgraduados, Campus Veracruz, Km 88.5 Carretera Federal Xalapa-Veracruz, vía Paso de Ovejas \\ entre Paso San Juan y Puente Jula, Tepetates, Veracruz, México. C.P. 91690. Apartado Postal 421 Veracruz, Ver. \\ C.P. 91700 . México \\ ${ }^{2}$ Instituto Tecnológico de Boca del Río. División de Estudios de Posgrado e Investigación, Km.12 Carretera \\ Veracruz-Córdoba. Boca del Río, Ver. C.P. 94290, México \\ Correspondence: Cesáreo Landeros-Sánchez, Colegio de Postgraduados, Campus Veracruz, Km 88.5 Carretera \\ Federal Xalapa-Veracruz, vía Paso de Ovejas entre Paso San Juan y Puente Jula, Tepetates, Veracruz, México. \\ C.P. 91690. Apartado Postal 421 Veracruz, Ver. C.P. 91700. México. Tel: 1-229-201-0770. E-mail: \\ clandero@colpos.mx
}

Received: March 13, 2012 Accepted: March 26, 2012 Online Published: May 29, 2012

doi:10.5539/jas.v4n7p186 URL: http://dx.doi.org/10.5539/jas.v4n7p186

\begin{abstract}
Agriculture, animal husbandry, fisheries and aquiculture have caused negative impacts to rivers, ground waters, and coastal lagoon systems as well as to associated systems. The objective of this study was to determine pollutant concentrations in groundwater from surface wells or water wheels in aquatic farms located along the river, and in lagoon systems, located in the state of Veracruz, Mexico, and their possible risks for human health. Concentrations of nitrates, total coliforms (TC), and Vibrio sp. were determined as well as temperature, salinity, dissolved oxygen, and $\mathrm{pH}$. The results showed that some values of physical, chemical and biological parameters in groundwater and different aquatic systems were beyond the levels established by the Mexican official norm. Farm effluents had TC levels higher than $2419 \mathrm{MPN} 100 \mathrm{~mL}^{-1}$ and dissolved oxygen was at a minimum value of $1.7 \mathrm{mg} \mathrm{L}^{-1}$, concentrations beyond the fixed standards. Likewise, the presence of Vibrio sp. was detected in lagoon systems, which is an indicator of water contamination. We conclude that the impact of production activities leads to human health risks.
\end{abstract}

Keywords: health risk, nitrates, coliform, Vibrio sp., lagoon system

\section{Introduction}

Mexico covers 1,964,375 $\mathrm{km}^{2}$ and has a mean annual precipitation of $772 \mathrm{~mm}$. However, its spatial and temporal distribution is irregular, with $42 \%$ of its territory, especially in the North, having a mean annual precipitation less than $500 \mathrm{~mm}$. In some cases, as in the zones of the Colorado River, it is less than $50 \mathrm{~mm}$. In contrast, in $7 \%$ of the territory there are regions with annual mean precipitation higher than $2,000 \mathrm{~mm}$, and some zones where it exceeds $5,000 \mathrm{~mm}$ annually. Most (67 to $80 \%$ ) precipitation occurs during the summer (Arreguim, Martínez, \& Trueba, 2004; Cantú \& Garduño, 2004).

The National Water Commission has identified 653 aquifers in Mexican national territory. Approximately 200 of these have been subjected to one or more studies and the available volume for 188 aquifers has been published in the Official Federal Diary. Thus, two thirds of Mexican aquifers have not been drawn on a map, and their geography, available water volume and other basic information are not known. Groundwater is one of the main sources of supply for domestic use and for irrigation all over the world (Celis, 2009), and provides $70 \%$ of the drinking water in Mexico (Marín, 2002).

In Mexico there are problems related to the freshwater of rivers, aquifers, and lagoon systems, especially: a) over-exploitation of aquifers, and b) pollution; the latter being mainly anthropogenic. Anthropogenic pollution can be divided into two types: inorganic and organic (Barrera \& Wong, 2005). One of the most serious problems in the 
country is bacteriological contamination, a phenomenon mainly associated with the lack of sewage treatment (Allegre, Moulin, Maisseu, \& Chabrit, 2005).

Approximately $90 \%$ of the urban environment is serviced by sewer systems, compared to $37 \%$ in terms of rural coverage, and $76 \%$ at a national level. Although the capacity for treatment of municipal sewage water is $81 \mathrm{~m}^{3} \mathrm{~s}^{-1}$, only $51 \mathrm{~m}^{3} \mathrm{~s}^{-1}$ are treated. Some years ago, on the Yucatan Peninsula, the death of $60 \%$ of children younger than 5 years was caused by pathogens transported by groundwater (Tolcachier, 2001).

As an example of inorganic water pollution, contributions of arsenic from sanitary backfill have been discussed (Marín, Leal, Rubio, \& Prieto, 2001). The presence of nitrates in groundwater has been reported by Galaviz-Villa et al. (2010); Pacheco and Cabrera (1997); Pacheco, Pat, \& Cabrera (2002); and Steinich, Escolero, \& Marín (1998). The occurrence of some contaminants in water and generally in aquatic systems has been quantified through their bioaccumulation in indicator organisms such as the oyster, Crassostrea virginica, and the brown shrimp, Fartantepenaeus aztecus (Lango, Landeros, \& Castañeda, 2010; Palomarez, Castañeda, Lango, \& Landeros, 2009). Water pollution is associated with health problems such as sewage use in agriculture in Irrigation Districts 03 and 100 in Central Mexico, where the risk of infection by Ascaris lumbricoides in children has been detected. Furthermore, children of highly exposed families also showed greater prevalence of diarrheic diseases (Cifuentes et al., 1993).

Studies carried out in England demonstrated that nitrates cannot be excluded as etiological factors in the development of gastric cancer and the mortality incurred (Peter \& Clough, 1983). A statistically significant correlation was found $(\mathrm{r}=0.67)$ between this type of cancer and consumption of water contaminated with nitrates (Sandor, Kiss, Farkas, \& Ember, 2001). Trejo and Bonilla (2001) analyzed seventy-three wells from the drinking water supply network in Aguascalientes and found a concentration of $\leq 1.5 \mathrm{mg} \mathrm{L}^{-1}$ of fluorides, the maximum permissible value established by current Mexican regulations (NOM-127-SSA1-1994). All the maximum doses of exposure surpassed the minimum risk level $\left(0.7\right.$ a $1.2 \mathrm{mgL}^{-1}$ ) established by ATSDR (Agency for Toxic Substances and Disease Registry). Likewise, it was determined that the estimated fluoride exposure doses through water consumption, and their comparison with those obtained in other states of Mexico, represented potential risks for public health in this urban area. It is recommended that the fluoride content in water for human consumption in this city should be reduced to $0.69 \mathrm{mg} \mathrm{L}^{-1}$ (Trejo \& Bonilla, 2001).

Water pollution through production activities in the different aquatic systems depends on the magnitude of the contaminant. Based on Lugo (1978), pollution is a function of eight components: 1) intensity of the contaminant; 2) multiplicative or additive effects that the impact of the contaminant may have on the general function of the ecosystem and its homeostasis; 3) the frequency of its occurrence; 4) the type of ecosystem; 5) the condition of the ecosystem; 6) intensity of other contaminants in the ecosystem; 7) residual effects of other pollutants in the system; and 8) frequency of other acting contaminants. These components contribute collectively with the contaminant in question, by altering the flow of energy, or affecting a substantial portion of the producers (organisms of the system) and provoking a reduction of the system's capacity to recuperate.

In accordance with the concept of the new water culture, we have identified four fundamental water uses whose implementation reflects different priorities in the political plan: 1. Water as a human right; 2. Water for environmental needs; 3. Water for social and community use; and 4. Water for economic development (Carvajal \& Chavira, 1985). To satisfy these needs we must recognize the status of our sources of supply; therefore the objective of this study was to determine the concentration of contaminants in the groundwater from surface wells or water wheels, influents and effluents of aquatic farms along the Jamapa River, and in the lagoon systems of Pueblo Viejo, Mandinga and Alvarado, and their possible risks to human health.

\section{Materials and Methods}

\subsection{Study Zones}

The research was carried out in three zones of the state of Veracruz; the first corresponds to an area of approximately 1,000 ha and groups several localities within the sugar cane zones of Irrigation Module (1-1) La Antigua (Figure 1). Seven sampling points of groundwater from surface wells or water wheels ( 3 to $15 \mathrm{~m}$ depth) for drinking water were randomly established, and were situated in the localities of Tolome, Loma Fina, El Tejón, Carretas, Faisán, La Víbora, Salmoral, and La Posta. The second zone is the one corresponding to the low basin of the Jamapa River, where the influents and effluents of the aquatic farms "La Rayana", "Las Gualdras", and "Aquaguadalupe" (Arroyo Moreno) are located. The third zone corresponds to the lagoon systems of Pueblo Viejo, Alvarado, and Mandinga (Figure 1). 


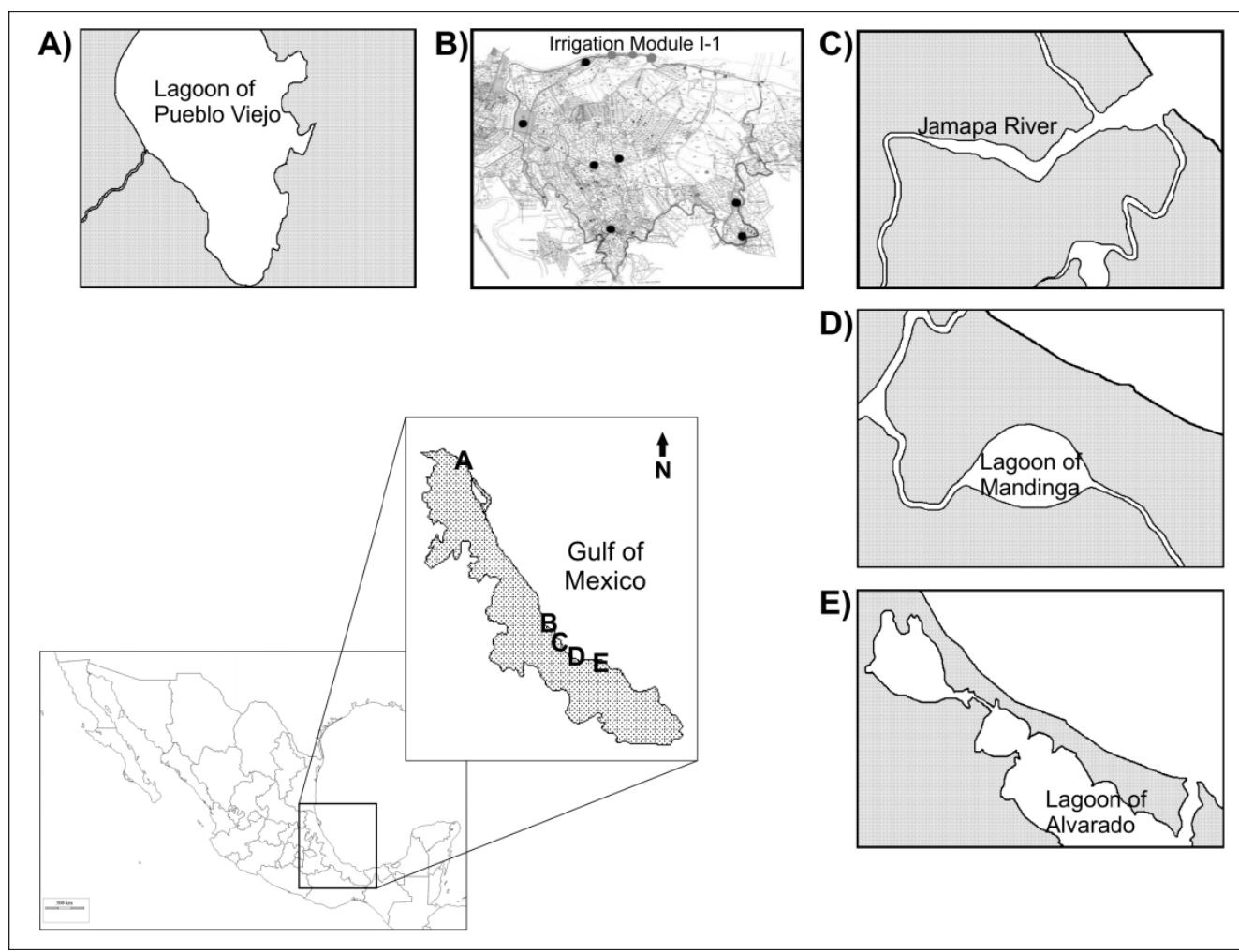

Figure 1. Location of study zones A, D, and lagoon systems (E); Sugar cane zone of Irrigation module I-1 (B); Stream channel of the low basin along the Jamapa River, Veracruz, Mexico (C)

During 2009, three sample collections were performed for the first zone, one for each of the studied periods. For this purpose we considered the climatological seasons prevailing during the study period, proposed by Farías (1991), corresponding to 'nortes' (windy period) (November-February), dry period (March-June), and the rainy season (July-October). Water samples were taken in surface wells (water wheels) according to Official Mexican Norm NOM-014-SSA1-1993. In order to determine nitrates, a volume of $500 \mathrm{~mL}$ water was collected in glass bottles, which were stored at $4{ }^{\circ} \mathrm{C}$ prior to their analysis. Nitrate concentration was determined according to Mexican Norm NMX-AA-079-SCFI-2001.

In the second zone, the sampling sites for evaluating influents and effluents of the above mentioned aquatic farms were located on the left bank of the Jamapa River. Water samples were taken in triplicate in order to determine total coliforms (TC) in the laboratory, based on Official Mexican Norm NOM-112-SSA1-1994, published in 1995 in the Official Federal Record. For the determination of dissolved oxygen (DO), temperature $\left({ }^{\circ} \mathrm{C}\right), \mathrm{pH}$, and salinity a YSI 6000 multi-parameter probe (YSI Inc. Yellow Springs, OH, USA) was used.

For the third zone, water samples were taken from five Crassostrea virginica oyster extraction zones in the three lagoon systems (Pueblo Viejo, Alvarado, and Mandinga) in order to determine total coliforms and Vibrio sp.

\subsection{Determining Nitrate Concentrations}

For each water sample, $\mathrm{NO}_{3}$ concentration was determined, according to the techniques described in Mexican Standard NMX-AA-079-SCFI-2001 for water analysis, determination of nitrates in natural water, drinking water, sewage, and treated waste water. In order to assess the contamination level of the different sources of water supply, we took the Official Mexican Norm NOM-127-SSA1-1994 as a reference; environmental health, water for human use and consumption, permissible limits of quality and treatments, to which drinking water must be subjected.

\subsection{Determining Physico - Chemical Parameters}

The farms "La Rayana", "Las Gualdras", and "Aquaguadalupe" were visited in order to obtain water samples for chemical and biological determinations. At all the sampling sites physico-chemical variables of water (temperature, salinity, $\mathrm{pH}$, and dissolved oxygen) were recorded using a YSI 6000 multi-parameter probe.

\subsection{Microbiological Analyses}

The methodologies established in the Official Mexican Standards were utilized for total and fecal coliforms and Vibrio sp. (published in the Official Federal Diary 1995, NOM-112-SSA1-1994, NOM-029-SSA1-1993). 


\subsubsection{Total Coliforms}

The technique consisted of using multiple fermentation tubes (dilution in tube) for determining the most probable number (MPN), which provides a statistical estimate of the present microbial density, based on the positive reaction of the culture. The method is based on coliform bacteria fermenting lactose when incubated at $35 \pm 1{ }^{\circ} \mathrm{C}$ (total coliforms) or $44.5^{\circ} \mathrm{C}$ (fecal coliforms) for 24 to $48 \mathrm{~h}$, resulting in acid and gas production which becomes evident during fermentation. Ten milliliters of water sample were inoculated in 5 tubes with $10 \mathrm{ml}$ of double concentration lactose broth and two tubes with $10 \mathrm{ml}$ of lactose broth of simple concentration, adding 1.0 and 0.1 $\mathrm{ml}$, respectively.

\subsubsection{Vibrio sp. Determination}

Pre-enrichment of Vibrio was made in $225 \mathrm{ml}$ of alkaline peptone broth to inoculate $25 \mathrm{ml}$ of the water sample, which were incubated at $35 \pm 1{ }^{\circ} \mathrm{C}$ for 18 to 24 hours. Subsequently, a portion of each dilution was taken for inoculation using the crossed stria selective agar Thiosulfate-Citrate-Bile Salts-Sucrose (TCBS) (Merck ${ }^{\circledR}$, Germany), placed in Petri dishes and incubated at $35^{\circ} \mathrm{C}$ for a period of 24 to 48 hours (Olafsen, Mikkelsen, Giaever, \& Hansen, 1993). Colonies of Vibrio sp. were identified using tests of oxidase, catalase, re-seeding in nutritive medium at $0,3,6,8$, and $10 \% \mathrm{NaCl}$, fermentation of glucose, lactose, manitol, sucrose, and indol production, test of methyl red, Voges Proskauer, urea hydrolysis, gelatin hydrolysis, use of citrate, fermentative-oxidative (OF) reaction, mobility, and $\mathrm{H}_{2} \mathrm{~S}$ production.

\subsection{Statistical Analyses}

Statistical analysis of the data was conducted using STATISTICA version 7.0. Parametric (ANOVA) and multivariate analyses (principal components and discriminant analyses) were performed. The results obtained from microbiological determinations were analyzed using descriptive statistics because the data obtained were just compared with standards given in the Mexican regulations, with classification by levels for total coliforms according to Welch, David, Clarke, Trinidade, \& Penner (2000).

\section{Results}

\subsection{Determination of Nitrates in Groundwater}

The analysis of variance of nitrate concentrations from surface wells or water wheels, situated in the different localities, did not show significant differences among seasons (Figure 2), but was significant among localities $(\mathrm{p}<0.05)$. The highest concentration was obtained from the public well in Tolome $\left(7.77 \mathrm{mg} \mathrm{L}{ }^{-1} \mathrm{~N}_{-} \mathrm{NO}_{3}\right)$ and the lowest from Faisán and La Posta (0.36 and $0.70 \mathrm{mg} \mathrm{L}^{-1} \mathrm{~N}^{-\mathrm{NO}_{3}}$, respectively).

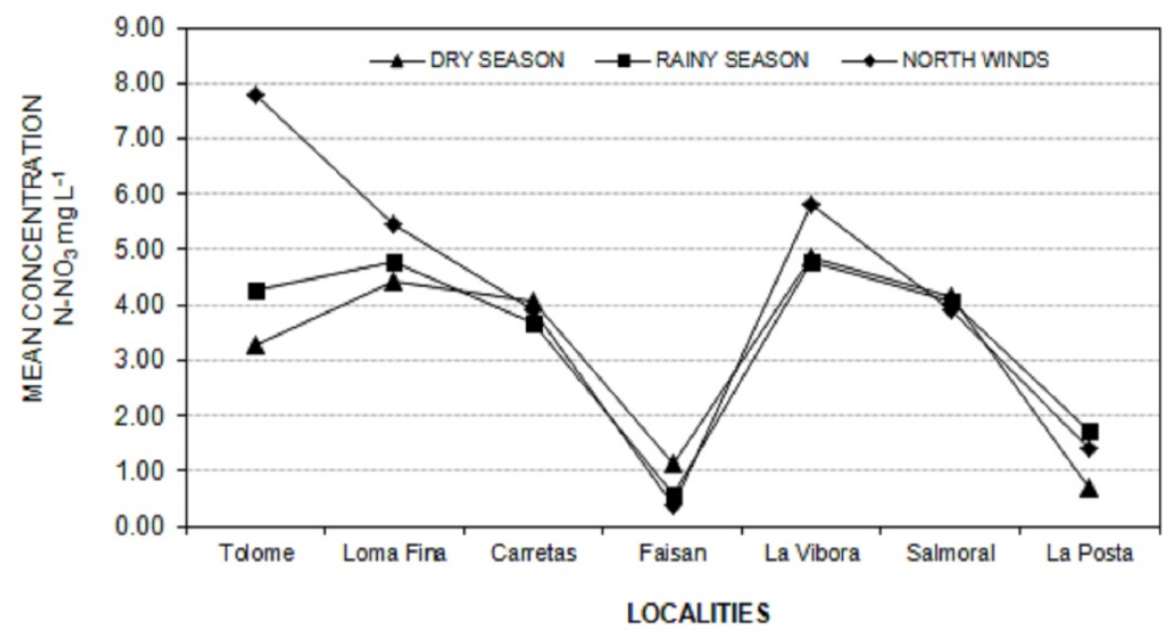

Figure 2. Mean concentration of nitrates $\left(\mathrm{N}^{-\mathrm{NO}_{3}} \mathrm{mg} \mathrm{L}^{-1}\right)$ per locality and per season, in groundwater.

\subsection{Determination of Total Coliforms in Influents and Effluents of the Aquatic Farms Along the Jamapa River}

Table 1 presents total coliform (TC) concentrations and physico-chemical parameters during the three seasons and in the different sampling zones. 
Table 1 . Mean concentration and level of water quality parameters for each of the sites and seasons during sampling

\begin{tabular}{|c|c|c|c|c|c|c|}
\hline Seasons and Sampling sites & Content & Total coliform (MPN 100mL $\mathrm{mL}^{-1}$ ) & $\begin{array}{c}\text { Temperature } \\
\left(\mathrm{T}^{\circ} \mathrm{C}\right)\end{array}$ & $\begin{array}{c}\text { Salinity } \\
\text { (USP) }\end{array}$ & Dissolved oxygen $\left(\mathrm{mgL}^{-1}\right)$ & $\mathrm{pH}$ \\
\hline \multicolumn{7}{|l|}{ Dry season } \\
\hline \multirow[t]{2}{*}{ La Rayana } & Mean & $>2419$ & 28.6 & 0.6 & 6.5 & 7.5 \\
\hline & Range & - & $27.9-29.2$ & $0.4-0.8$ & $5.8-7.7$ & $7.4-7.6$ \\
\hline \multirow[t]{2}{*}{ Las Gualdras } & Mean & $>2419$ & 28.9 & 0.9 & 5.6 & 7.6 \\
\hline & Range & - & $28.0-29.6$ & $0.5-1.2$ & $5.3-6.0$ & $7.6-7.7$ \\
\hline \multirow[t]{2}{*}{ Aquaguadalupe } & Mean & $>2419$ & 31.6 & 10.7 & 3.2 & 7.4 \\
\hline & Range & - & $30.6-32.4$ & $9.1-13.0$ & $1.7-4.8$ & $7.4-7.6$ \\
\hline \multicolumn{7}{|l|}{ Rainy season } \\
\hline \multirow[t]{2}{*}{ La Rayana } & Mean & 1330 & 30.4 & 0.4 & 5.4 & 7.5 \\
\hline & Range & $1062-1711$ & $29.7-31.3$ & $0.1-0.7$ & $4.7-6.3$ & $7.4-7.6$ \\
\hline \multirow[t]{2}{*}{ Las Gualdras } & Mean & 1185 & 30.6 & 0.5 & 5.8 & 7.6 \\
\hline & Range & $990-1296$ & $29.8-31.5$ & $0.1-0.9$ & $4.9-6.9$ & $7.5-7.6$ \\
\hline \multirow[t]{2}{*}{ Aquaguadalupe } & Mean & 1866 & 33.4 & 4.9 & 3.5 & 7.5 \\
\hline & Range & $1598-2275$ & $32.8-33.8$ & $4.3-5.7$ & $3.1-4.0$ & $7.3-7.7$ \\
\hline \multicolumn{7}{|l|}{ North Winds } \\
\hline \multirow[t]{2}{*}{ La Rayana } & Mean & $>2419$ & 24.8 & 0.2 & 5.9 & 8.0 \\
\hline & Range & - & $24.4-25.2$ & $0.1-0.3$ & $5.7-6.1$ & $8.0-8.1$ \\
\hline \multirow[t]{2}{*}{ Las Gualdras } & Mean & $>2419$ & 24.9 & 0.6 & 5.6 & 8.0 \\
\hline & Range & - & $24.5-25.8$ & $0.4-0.7$ & $5.3-5.9$ & $7.9-8.1$ \\
\hline \multirow[t]{2}{*}{ AquaGuadalupe } & Mean & $>2419$ & 27.1 & 6.8 & 3.5 & 7.7 \\
\hline & Range & - & $25.9-28.0$ & $6.0-7.6$ & $3.3-3.7$ & $7.6-7.8$ \\
\hline
\end{tabular}

Table 2. Total coliform concentrations in the lagoon systems of the Gulf of Mexico.

\begin{tabular}{|c|c|}
\hline \multirow[b]{2}{*}{ LAGOON SYSTEMS OF THE GULF OF MEXICO } & SEASON \\
\hline & North Winds Rainy season \\
\hline *Mandinga, Veracruz & $658.75 \mathrm{MPN}$ \\
\hline *Pueblo Viejo, Veracruz & $>2419 \mathrm{MPN}>2419 \mathrm{MPN}$ \\
\hline *Alvarado, Veracruz & $>230 \mathrm{MPN}$ \\
\hline \multirow[t]{4}{*}{ **Pueblo Viejo, Veracruz } & 400 MPN (Barrera et al., 1998) \\
\hline & 3 MPN (Rosas et al., 1985) \\
\hline & 91000 MPN (Barrera et al., 1995) \\
\hline & 525000 MPN (Guzám et al., 1995) \\
\hline **Tamiahua, Veracruz & 15000 MPN (Barrera et al., 1999) \\
\hline **El Conchal, Veracruz & 370 MPN (Rosas et al., 1985) \\
\hline **Boca de Atasta, Campeche & 5 MPN (Pica, 1988) \\
\hline **Sánchez Magallanes, Tabasco & 90000 MPN (Rodríguez, 1986) \\
\hline **Mecoacán, Tabasco & 15 MPN (Rosas et al., 1985) \\
\hline
\end{tabular}

Footnote: $*$ Results obtained in this study; $* *$ Mean annual values.

\subsection{Determination of Total and Fecal Coliforms and Vibrio sp. in Lagoon Systems}

Total and fecal coliform values obtained in the three lagoon systems had concentrations higher than 2,000 MPN $100 \mathrm{~mL}^{-1}$ (Table 2). Vibrio sp. was reported in $90 \%$ of all the lagoon systems. 
Table 5. Health risks posed by effects of chemically and biologically polluted water (adapted from Barrera \& Wong, 2005; Galaviz-Villa et al., 2010)

\begin{tabular}{|c|c|c|}
\hline \multicolumn{3}{|c|}{ Nitrates and Nitrites } \\
\hline Diseases & Disease Symptoms & Particular Case in Babies \\
\hline $\begin{array}{l}\text { Metahemoglobinemia in } \\
\text { small children, pregnant } \\
\text { women, fetus }\end{array}$ & $\begin{array}{l}\text { - Low acidity in the stomach of sucklings } \\
\text { allows growth of certain microorganisms } \\
\text { containing enzymes capable of reducing } \\
\text { nitrates to nitrites } \\
\text { - Fetal hemoglobin and erythrocytes in babies } \\
\text { are more susceptible to transformation into } \\
\text { metahemoglobin by nitrite action } \\
\text { The enzymatic system capable of reducing } \\
\text { metahemoglobin to hemoglobin is deficient in } \\
\text { the small child. Ingestion of liquid related to } \\
\text { body weight in a small child is higher than in } \\
\text { the adult. }\end{array}$ & $\begin{array}{l}\text { Their clinical symptoms are bluish } \\
\text { coloring of the skin and } \\
\text { brownish-gray blood color. }\end{array}$ \\
\hline \multicolumn{3}{|c|}{$\begin{array}{l}\text { Bacteriological Contamination } \\
\end{array}$} \\
\hline Transmitting Bacterium & Species & Symptoms \\
\hline \multirow{3}{*}{$\begin{array}{l}\text { Esherichia coli } \\
\text { Always associated with fecal } \\
\text { contributions }\end{array}$} & E. coli (enteropathogenic) & $\begin{array}{l}\text { Diarrheic syndromes mainly in } \\
\text { children } \\
\text { Secretory diarrhea or Traveler's } \\
\text { diarrhea } \\
\text { Inflammatory diarrhea attacks the } \\
\text { epithelial intestine }\end{array}$ \\
\hline & E. coli (causing Hemorrhage) internal & $\begin{array}{l}\text { Diarrhea with hemorrhage } \\
\text { includes strain O157: H7* having } \\
\text { shown resistance to antibiotics }\end{array}$ \\
\hline & & $\begin{array}{l}\text { * Catalogued as emergent } \\
\text { pathogens related to water }\end{array}$ \\
\hline Vibrio & V. parahaemolyticus & $\begin{array}{l}\text { Abdominal cramps, nausea, fever } \\
\text { associated with vomiting; } \\
\text { dehydration and death when there } \\
\text { is severe loss of electrolytes } \\
\text { Gastroenteritis }\end{array}$ \\
\hline
\end{tabular}

\section{Discussion}

\subsection{Nitrate and Nitrite Determination in Groundwater}

The differences among localities may be attributed to the types of management of nitrogenous fertilizers used by producers in the zone, as well as to the soil types and the depths of wells under study. For example, the well in Tolome is approximately $3 \mathrm{~m}$ deep, while the well in El Faisán has a depth of 10-15 $\mathrm{m}$. The latter agrees with Liu et al. (2005) who reported that the $\mathrm{N}-\mathrm{NO}_{3}$ concentrations in groundwater are significantly correlated with the depth of the well and concluded that if the well is deeper (150-200 m) nitrate concentrations diminish because of dilution.

The nitrate concentrations found in each of the localities during the three seasons are within the highest permissible limits $\left(50 \mathrm{mg} \mathrm{L}^{-1}\right)$ established by national and international standards (Guidelines 91/676/CEE, 1991; SSA, 1994; WHO, 2007). Nevertheless, to use this source of water for human consumption, its quality may be affected by the application of traditional techniques of water purification such as boiling, which has been shown to concentrate substances such as nitrates or sodium (Miñana, 2004).

According to Dukes and Evans (2006) higher nitrate concentrations have been found in farm lands than in those used for other purposes. The results suggest that nitrate concentrations in groundwater are attributed to fertilizers applied to regional grass and crops. Up to $20 \%$ of the increases in the doses of fertilizer are reported in order to improve the responses of crops, this application occurs despite problems with inefficient drainage which causes temporary flooding, compromising the normal supply of nitrogen to plants (Pacheco et al., 2002; Pacheco, Cabrera, \& Pérez, 2004).

An analysis of variance did not detect significant differences $(p<0.05)$ among localities or seasons. The greatest nitrite concentration occurred in Carretas and Tolome, with a value of $0.013 \mathrm{mg} \mathrm{L}^{-1}$ of N-NO $\mathrm{N}_{2}$ for both locations. These low concentrations in groundwater may be due to the $\mathrm{pH}$ of the farm soil at the moment of fertilizer application, since maintaining values lower than 7.0 promotes the transformation of nitrogenous fertilizers into 
nitrites (De Miguel \& Vázquez, 2006), allowing them to be transported via lixiviation towards the aquifer (Arauzo, Díez, \& Hernaíz, 2003; Feigenbaum, Bielorai, Erner, \& Dasberg, 1987).

The Veracruz aquifer is vulnerable to contamination by nitrates and nitrites. Infiltration or lixiviation of nitrogenous compounds through the soil profile reduces groundwater quality (Beltrami, 2001). This deterioration has a negative impact not only on neighboring localities within the agricultural zones but also on communities being supplied by the same aquifer, such as Boca del Rio, La Antigua, Jamapa, and Soledad de Doblado (CNA, 2009).

\subsection{Total Coliform Determination in Influents and Effluents of Aquatic Farms along the Jamapa River}

In microbiological studies conducted by Castañeda, Pardio, Orrantía, \& Lango (2005); on water from different lagoons in the state of Veracruz, high concentrations of total and fecal coliforms were detected, as well as the occurrence of $E$. coli, which were attributed to the discharge of untreated sewage from irregular human settlements established along the periphery of the lagoons. In 2003, the Ministry of Environment and Natural Resources (SEMARNAT, 2009) registered a concentration of 86,810 MPN $100 \mathrm{~mL}^{-1}$ of fecal coliforms (CF) in the Jamapa River, whereas in 2004, 1043 MPN $100 \mathrm{~mL}^{-1}$ of CF was found. Ramos, Vidal, \& Saavedra, (2008); reported this phenomenon and attributed it to a problem of dilution occurring along the route of flow from the source of emission, perhaps because water stratification promoted the ascension of the discharge to the surface.

Based on the physico-chemical water quality parameters, the Federal Law of Rights (Regulations Applicable with Regards to National Waters, 2011, published in the Official Federal Diary, 2011) established a natural temperature condition of $(\mathrm{NC})+1.5$, and is understood as the mean water temperature of a system under natural environmental conditions plus $1.5^{\circ} \mathrm{C}$ as a maximum permissible limit. The mean water temperature of the river was $28.6{ }^{\circ} \mathrm{C}$, and the maximum was $33.8^{\circ} \mathrm{C}$ (difference of $5.2^{\circ} \mathrm{C}$ ), which surpassed this limit. It is worth mentioning that the highest recorded temperature was during the rainy season in Arroyo Moreno, a site influenced by the effluents from CFE facilities that use the river water to cool boilers. As for the dissolved oxygen (DO) level, the regulations indicate a minimum of $5 \mathrm{mg} \mathrm{L}^{-1}$ in effluents, whereas in the river the registered minimum was $1.7 \mathrm{mg} \mathrm{L}^{-1}$ in Arroyo Moreno during the dry season (low water levels).

Table 3 shows that over the three seasons, Arroyo Moreno always had DO levels below the permissible minimum, because this site had the highest values of most chemical and biological parameters analyzed, and therefore had a greater DO demand for their oxidation.

In Aquaguadalupe (Moreno River), water temperature and salinity were also in higher concentration during the three seasons, whereas DO levels were lowest. Álvarez, Panta, Ayala, \& Acosta (2008), obtained $0 \mathrm{mg} \mathrm{L}^{-1}$ of DO in the Tulancingo River, as well as high concentrations of fecal coliforms, values that were beyond 24,000 MPN $100 \mathrm{~mL}^{-1}$; indicating that this river was strongly impacted by contamination. As mentioned above, the low DO is due to the biodegradation of organic matter and to the many pollutants present in the environment (Stanley, 2000).

Table 3. Comparison of water quality parameters of the sampling sites along the river (highest levels found) with those established in Mexican standards (Palomarez, 2010)

\begin{tabular}{|c|c|c|c|}
\hline Parameters & NOM-001-SEMARNAT-1996 & $\begin{array}{l}\text { Ley Federal de Derechos, } \\
2009^{2}\end{array}$ & Maximum value \\
\hline $\begin{array}{l}\text { Fecal coliforms } \\
\left(\mathrm{MPN} \cdot 100 \mathrm{~mL}^{-1}\right)\end{array}$ & 1,000 & 1,000 & $>2,419 *$ \\
\hline Temperature $\left({ }^{\circ} \mathrm{C}\right)$ & 40 & $\mathrm{NC}+1.5$ & 33.8 \\
\hline $\begin{array}{l}\text { Salinity } \quad\left(\mathrm{USP}^{3},\right. \\
\left.\mathrm{g} \cdot \mathrm{L}^{-1}\right)\end{array}$ & - & - & 16.3 \\
\hline $\begin{array}{l}\text { Dissolved oxygen } \\
\left(\mathrm{mg} \cdot \mathrm{L}^{-1}\right)\end{array}$ & 5 (minimum value) & 5 & $\begin{array}{l}7.8 \quad(1.7 \quad \text { minimum } \\
\text { value })\end{array}$ \\
\hline $\mathrm{pH}$ & - & $6.5-8.5$ & 8.15 \\
\hline
\end{tabular}

\footnotetext{
${ }^{1}$ Maximum permissible limits for the protection of aquatic life in freshwater; monthly mean

${ }^{2}$ Use 3: protection of aquatic life, representative values of a normal operation day

${ }^{3}$ Unit of Practical Salinity

*Total coliforms

$\mathrm{NC}$ : natural conditions
} 
Table 4. Interactions and conflicts of lagoon systems in the state of Veracruz (modified from Carvajal and Chavira, 1985)

\begin{tabular}{ll}
\hline Activity & Effect \\
\hline Fishery & $\begin{array}{l}\text { Pressure on natural populations and alterations of bottoms } \\
\text { Modification of neighboring zones, use of effluents and influents as supply and } \\
\text { discharge respectively }\end{array}$ \\
$\begin{array}{l}\text { Agriculture } \\
\text { Channel dredging }\end{array}$ & $\begin{array}{l}\text { Erosion; contamination by fertilizers and pollution from insecticides } \\
\text { Modification of coastal morphology and of system sedimentology and pressure } \\
\text { on natural populations } \\
\text { Contamination by fuels and noise } \\
\text { Modification of coastal morphology and of margins of aquatic systems, and } \\
\text { anthropogenic contamination }\end{array}$ \\
Urbanization & $\begin{array}{l}\text { Modification of morphology of margins of aquatic systems and alteration of } \\
\text { native flora and fauna } \\
\text { Contamination by industrial waste and pressure on natural populations } \\
\text { Roads, ways, and streets }\end{array}$ \\
$\begin{array}{l}\text { Industries } \\
\text { Use and resources of the }\end{array}$ & $\begin{array}{l}\text { Econe social, and political conflicts of the zone } \\
\text { zone }\end{array}$
\end{tabular}

4.3 Determination of Total Coliforms and Vibrio sp. in the Lagoon Systems

Given the lack of regulation of domestic and urban discharges, the lagoon systems are natural reservoirs of total and fecal coliform bacteria and Vibrio sp. However, as the bacterial levels in these systems surpass 1000 to 2000 MPN $100 \mathrm{~mL}^{-1}$, concentrations exceeding the limits established by Mexican regulations, the lagoon systems become risks for human health (Espina \& Vanegas, 2005). The lagoon systems in the state of Veracruz are zones of interaction and conflict, where several production activities converge (Table 4), primarily that of sugar cane. The inefficient regulation and management of nitrogenous fertilizers and water in this agricultural activity continues to promote pollution of the aquifer and surface waters (Landeros, Castañeda, Lango, Moreno, \& Palomarez, 2007). Aquaculture, primarily the cultivation of tilapia, generates an excess discharge of organic matter (Zetina, Reta, Olguín, Acosta, \& Espinosa, 2006). Urbanization also contributes a large amount of organic matter and pathogenic microorganisms to the water systems (Aguilar, Villanueva, Guzmán, \& Vazquez, 2006).

Carbajal and Chavira (1985), classified aquatic contaminants into two types: type 1 are contaminants which operate continuously, considerably reducing the possibility of mitigation or restoration (e.g. crude oil), while those that are type 2 divert some energy before it is incorporated into the system, and also removes potential energy after it is stored. They may be found in domestic and industrial discharge and in excessive applications of agricultural chemicals. Furthermore, they occur as results of habitat alterations, from the construction of dikes, dams, channels, and embankments. Types 3, 4, and 5, according to their intensity and frequency, refer to pollutants which may gradually alter the trophic structure of the system, with the consecutive modification of energy flow through the trophic web. Types 6 and 7 include contaminants having lesser impact on the ecosystem, since they do not affect energy flow because their effects become evident over the long term (e.g. heavy metals or pesticides). These are most important because of the indirect damage they may cause to man. This is also the case of total coliforms (Table 1) found in the Jamapa River, whose concentrations are beyond the standards, which remain throughout the year. Considering that this river is the source of recharge for the aquifers which supply water to wells and aquaculture farms in the Veracruz-Boca del Rio-Medellin region (a tourist and recreation zone), use of water from the Jamapa River constitutes a public health risk (Aguilar, 2007). Finally, anthropogenic activities (e.g. agriculture, animal husbandry, aquaculture, industry, and human settlements) yield different pollutants which negatively impact rivers, lagoons, and aquifers; water bodies that are not independent systems, but form part of the hydrological network in a given region. Therefore, systems exposed to pollution and environmental degradation eventually become sources of contamination for human wellbeing (Lavell, 1996).

4.4 An Alternative to Reduce and Control in the short-term Chemical and Biological Contaminants in Surface and Subterranean Water

As pointed out by Galaviz-Villa et al. (2010), in the short-term, extension and outreach programs/workshops can be implemented not only to teach people about the dangers of such contaminated waters, but to inform them of the different reduction/treatment options available, and to train them to use probes or other methods to monitor the chemical and biological contaminants in their surface and groundwater supplies. 


\section{Conclusions}

Water pollution from production and other anthropogenic activities has led to deterioration of water quality in the different aquatic systems in this report, by altering the concentration of some physical, chemical, and biological parameters of water beyond the permissible limits established by Mexican standards. The resulting contamination is a risk to human health, particularly for water extracted from aquifers, since chemical and microbiological contaminants are transmitted to man through the consumption of unsanitary water, domestic activities, or when it contaminates aquatic organisms in aquaculture or other fisheries. This consumption can lead to acute or chronic human disease.

\section{Acknowledgements}

Thanks to Consejo Nacional de Ciencia y Tecnología (CONACYT), the Colegio of Postgraduados, Campus Veracruz ("LP18 Impacto y Mitigación del Cambio Climático"), and to the Instituto Tecnológico de Boca del Rio for financial support.

\section{References}

Acta Oceanologica Sinica. (2005). The characteristics of $\mathrm{NH}_{4}^{+}-\mathrm{N}$ adsorption on intertidal sediments of the Changjiang Estuary in China. Shanghái, China: Liu, M., Hou, L. J., Xu, S. Y., Jiang, H. Y., Ou, D. N., Yu, J., Wang, Q.

Aguilar, I. A. S., Villanueva, F. P., Guzmán, A. A., \& Vázquez B. (2006). La contaminación del agua como una externalidad para la producción pesquera y acuícola. México: Guzmán Amaya P. y Fernán Fuentes Castellanos.

Aguilar, M. A. G. (2007). Análisis del crecimiento urbano e impacto en el ambiente biofisico del área conurbada de la ciudad de Veracruz: el caso del municipio de boca del río. México D.F.

Allegre, C., Moulin, P., Maisseu, M., \& Chabrit F. (2005). Treatment and reuse of reactive dyeing effluents. $J$. Memb. Sci., 269, 15-34. http://dx.doi.org/10.1016/j.memsci.2005.06.014

Álvarez, P. A. J., Panta, E. R. J., Ayala, R. C., \& Acosta H. E. (2008). Calidad Integral del Agua Superficial en la Cuenca Hidrológica del Río Amajac. Información Tecnológica, 19(6), 21-32. http://dx.doi.org/10.1612/inf.tecnol.3975it.07

Arauzo, M., Díez, J. A., \& Hernáiz, P. (2003). Estimación de balances hídricos y lixiviación de nitratos en sistemas agrícolas. In Álvarez-Benedí, J., Marinero, P (eds.), Estudios de la Zona No Saturada del Suelo (pp. 6 39-44). Castilla León: Valladolid.

Arreguim, C. F. I., Martínez, A. P., \& Trueba V. (2004). El Agua en México y su Perspectiva Científica y Tecnológica. In Jiménez Cisneros, B., Marín, L. E., Escolero Fuentes, O., Alcocer, J (eds.), El Agua en México: Una Vista desde la Academia (pp. 403). México: Academia Mexicana de Ciencias.

Barrera-Escorcia, G., \& Wong-Chang I. (2005). Contaminación por microorganismos en zonas costeras. In Botello, A.V., J. Rendón von Osten, G. Gold-Bouchot y C. Agraz-Hernández (eds.), Golfo de México, contaminación e impacto ambiental (pp. 475-486). México: INE.

Beltrami, C. (2001). La Contaminación. Buenos Aires: Longseller.

Cantú, M., \& Garduño H. (2004). Administración de Derechos del Agua: de regularización a eje de la gestión de los recursos hidráulicos. In Jiménez Cisneros, B., Marín, L. E., Escolero Fuentes, O., Alcocer, J (eds.), El Agua en México (pp. 403). México: Academia Mexicana de Ciencias.

Carvajal, P. J. L., \& Chavira M. D. (1985). La contaminación en los sistemas lagunar - estuarino de las costas mexicanas. Elementos, 10(2), 58-64.

Castañeda, C. M. R., Pardio, S. V., Orrantía, B. E., \& Lango R. F. (2005). Influence of water temperature and salinity on seasonal occurrences of Vibrio cholerae and enteric bacteria in oyster-producing areas of Veracruz, México. Marine Pollution Bulletin, 50, 1641-1648. http://dx.doi.org/10.1016/j.marpolbul.2005.06.036

Celis, H. B. (2009). Contaminación de aguas subterráneas por hidrocarburos líquidos livianos en fase no acuosa. Ciencia Ahora, 22(11), 20-29.

Cifuentes, E., Blumenthal, U., Ruiz, P. G., Bennett, S. A., Quigley, M., \& Romero A. H. (1993). Problemas de salud asociados al riego agrícola con agua residual en México. Salud Pública de México, 35(6), 614-619

Comisión Nacional de Agua. (2009). Plan Director para la modernización Integral del Riego del Distrito de Riego 035, La Antigua, Veracruz. La Antigua, Veracruz: CNA. 
De Miguel, F. C., \& Vásquez, T. M. (2006). Origen de los nitratos y su influencia en la potabilidad de las aguas subterráneas. Minería y Geología, 22(3), 1-9.

Directiva del Consejo Comunidad Económica Europea. (1991). Relativa a la protección de las aguas contra la contaminación producida por nitratos utilizados en la agricultura. Directiva 91/676/CEE.

Dukes, M. D., \& Evans, R. O. (2006). Impact of agriculture on water quality in the North Carolina Middle Coastal Plain. Journal of Irrigation and Drainage Engineering, 132(3), 250-262. http://dx.doi.org/10.1061/(ASCE)0733-9437(2006)132:3(250)

Espina, S., \& Vanegas, C. (2005). Ecofisiología y contaminación. In A.V. Botello., J. Rendón-Von Osten., G. Gold-Bouchot y C. Agraz-Hernández (eds.), Golfo de México Contaminación e Ompacto ambiental: Diagnostico y Tendencias (53-78). Mexico D. F.

Farías, S. J. A. (1991). Ecology, culture and utilization of the mussel Brachiodontes recurvus (Rafinesque), in the context of an integrated management approach to Boca del Rio-Mandinga estuarine system, Veracruz, México. Tesis doctoral, Universidad de Stirling, Escocia.

Feigenbaum, S., Bielorai, H., Erner., \& Dasberg, S. (1987). The fate of N labeled nitrogen applied to mature citrus trees. Journal of Plant and Soil, 97, 179-187. http://dx.doi.org/10.1007/BF02374940

Galaviz, V. I., Landeros, S. C., Castañeda, C. M. R., Martínez, D. J. P., Pérez, V. A., Nikolskii, G. I., \& Lango R. F. (2010). Agricultural contamination of subterranean water with nitrates and nitrites: An environmental and public health problem. Journal of Agricultural Science, 2(2), 1916-9760

IX Simposio Internacional y IV Congreso Nacional de agricultura sostenible. (2007). Contaminación del agua por nitrógeno causada por la agricultura en zonas cañeras de Veracruz, México ( $1^{\mathrm{ra}}$ ed.,). Veracruz, México: Landeros S. C., Castañeda C. M. R., Lango R. F., Moreno S. J. C., \& Palomarez G. M.

Lango, R. F., Landeros, S. C., \& Castañeda, C. M. R. (2010). Bioaccumulation of cadmium (Cd), lead (Pb) and arsenic (As) in Crassostrea virginica (Gmelin, 1791), from Tamiahua lagoon system, Veracruz, México. Revista Internacional de Contaminación Ambiental, 26(3), 201-210.

Lavell, A. (1996). Degradación ambiental, riesgo y desastre urbano. Problemas y conceptos: hacia la definición de una agenda de investigación. In Agusta Fernández m. (ed.), Ciudades en Riesgo degradación ambiental, riesgos urbanos y desastres (pp.140). Lima, Peru: Red de estudios sociales en prevención de desastres en América Latina.

Marín, L. E. (2002). Perspectives on Mexican ground water resources. Ground Water, 40(6), 570-571. http://dx.doi.org/10.1111/j.1745-6584.2002.tb02542.x

Marín, L. E., Leal, B. R. M., Rubio, R., \& Prieto, E. (2001). Geochemistry of the Chiltepec sanitary landfill, Puebla, Mexico. Geofisica Internacional, 40(4), 301- 308.

Miñana, V. (2004). Agua de bebida en el lactante. Anales de Pediatria, 60, 161-9.

NMX-AA-079-SCFI-2001. (2001). Análisis de aguas - determinación de nitratos en aguas naturales, potables, residuales y residuales tratadas - método de prueba [Online] Available http://www.sma.df.gob.mx/sma/links/download/archivos/secofi_nmx_aa_079_scfi_2001.pdf

NOM-001-SEMARNAT-1996. (1996). Norma Oficial Mexicana que establece los límites máximos permisibles de contaminantes en las descargas de aguas residuales en aguas y bienes nacionales [Online] Available http://www.bvsde.paho.org/bvsacd/cd38/Mexico/NOM001ECOL.pdf

NOM-014-SSA1-1993. (1993). Norma Oficial Mexicana Procedimientos sanitarios para el muestreo de agua para uso y consumo humano en sistemas de abastecimiento de agua públicos y privados [Online] Available http://www.salud.gob.mx/unidades/cdi/nom/014ssa13.html

NOM-110-SSA1-1994. (1994). Norma oficial mexicana, bienes y servicios. Preparación y dilución de muestras de alimentos para su análisis microbiológico [Online] Available http://www.salud.gob.mx/unidades/cdi/nom/110ssa14.html

NOM-112-SSA1-1994. (1994). Bienes y servicios. Determinación de bacterias coliformes. Técnica del número más probable [Online] Available http://www.salud.gob.mx/unidades/cdi/nom/112ssa14.html

NOM-127-SSA1-1994. (1994). Salud ambiental, agua para uso y consumo humano. Límites permisibles de calidad y tratamientos a que debe someterse el agua para su potabilización [Online] Available http://www.salud.gob.mx/unidades/cdi/nom/127ssa14.html

Olafsen, J. A., Mikkelsen, H. V., Giaever, H. M., \& Hansen, G. H. (1993). Indigenous bacteria in hemolymph and tissues of marine bivalves at low temperatures. Applied and Environmental Microbiology, 59, 1848-1854. 
Pacheco, A. J., Pat, C. R., \& Cabrera, S. A. (2002). Análisis del ciclo del nitrógeno en el medio ambiente con relación al agua subterránea y su efecto en los seres vivos. Ingeniería, Revista Académica de la Facultad de Ingeniería Universidad Autónoma de Yucatán, 6(3), 73-81.

Pacheco, A. J., Sauri, R. M., \& Cabrera, S. A. (1997). Impacto de la porcicultura en el medio ambiente. Ingenieria, Revista Académica de la Facultad de Ingeniería Universidad Autónoma de Yucatán, 1(3), 53-59.

Pacheco, J., Cabrera, A., \& Pérez, R. (2004). Diagnostico de la calidad del agua subterránea en los sistemas municipales de abastecimiento en el Estado de Yucatán, México. Ingeniería, Revista Académica de la Facultad de Ingeniería Universidad Autónoma de Yucatán, 8(2), 165-179.

Palomarez, G. J. M. (2010). Valoración de la calidad de los influentes y efluentes de las granjas acuicolas de la cuenca baja del Rio Jamapa, Veracruz. Tesis de Doctorado, Colegio de Postgraduados, Veracruz, México.

Palomarez, G. J. M., Castañeda, C. M. R., Lango, R. F., \& Landeros, S. C. (2009). Niveles de metales pesados en el camarón café Fartantepenaeus aztecus de la laguna de Tamiahua, Veracruz. Revista de Investigación Marina, 30(1), 63-69.

Peter, W., \& Clough, L. (1983). Nitrates and gastric carcinogenesis. Environmental Geochemistry and Health, 5(2-3), 91-95. http://dx.doi.org/10.1007/BF02084905

Ramos, O. L. M., Vidal, L. A., \& Saavedra D. L. M. (2008). Análisis de la contaminación microbiológica (coliformes totales y fecales) en la Bahía de Santa Marta, Caribe colombiano. Acta Biológica Colombiana, 13(3), 85-96.

Reglamento de Ley de Aguas Nacionales. (2011). Publicado en el Diario Oficial de la Federación el 29 de agosto de 2011. [Online] Available http://sirev.profepa.gob.mx/innovaportal/file/1200/1/Conv\%202-2011.pdf

Sandor, J., Kiss, I., Farkas, O., \& Ember I. (2001). Association between gastric cancer mortality and nitrate content of drink water: Ecological study on small area inequalities. European Journal of Epidemiology, 17(5), 443-447.

SEMARNAT. (2009). Compendio de Estadísticas Ambientales. Distribución de las estaciones de monitoreo de calidad del agua superficial, según categoría de DBO5 por región Hidrológico-Administrativa. [Online] Available: http://app1.semarnat.gob.mx/dgeia/informe_2008/compendio_2008/03_ambiental.html

SSA. (1994). Secretaría de Salud. NOM-127-SSA1-1994. Salud ambiental, agua para uso y consumo humano. Límites permisibles de calidad y tratamientos a los que debe someterse el agua para su potabilización. [Online] Available http://www.salud.gob.mx/unidades/cdi/nom/m127ssa14.html

Stanley, E. M. (2000). Water pollution. In Stanley E. Manahan (ed.), Fundamentals of Environmental Chemistry (pp. 1024). Boca Raton, USA: CRC Press.

Steinich, B., \& Marin, L. E. (1997). Determination of flow characteristics in the aquifer of the northwestern Peninsula of Yucatan, Mexico. Journal of Hydrobiology, 191, 315-331.

Steinich, B., Escolero, O., \& Marín, L. E. (1998). Salt-water intrusion and nitrate contamination in the Valley of Hermosillo and El Sahuaral coastal aquifers, Sonora, Mexico. Hydrogeology Journal, 6, 518-526.

Technical Information Center US Department of Energy. (1978). Stress and ecosystem. In Energy and Environmental Stress in Aquatic Ecosystems., J. H. Thorp and J. W. Gibbons. Washington, DC: Lugo, A. E.

Tolcachier, A. J. (2001). Temas de Medicina Ambiental: Contaminación del Agua. [Online] Available http://medioambiente.gov.ar/archivos/web/salud_ambiente/File/8.pdf

Trejo, V. R., \& Bonilla, P. A. (2001). Exposición a fluoruros del agua potable en la ciudad de Aguascalientes, México. Revista Panamericana de Salud Pública, 10, 108-113.

Welch, P. D. J., Clarke, W., Trinidade, A., \& Penner, D. (2000). Microbial quality of water in rural communities of $\begin{array}{lllll}\text { Trinidad. Revista Panamericana de Salud Publica, 8, } & \text { 172-180. }\end{array}$ http://dx.doi.org/10.1590/S1020-49892000000800004

WHO. (2007). Nitrate and nitrite in drinking water. Background document for development of World Health Organization guidelines for drinking-water quality. [Online] Available http://www.who.int/water_sanitation_health/dwq/chemicals/nitratenitrite2ndadd.pdf

Zetina, C. P., Reta, M. J. L., Olguín, P. C., Acosta, B. R., \& Espinosa, S. G. (2006). El cultivo de tilapia (Oreochromis spp) en la rentabilidad de seis agroecosistemas en el estado de Veracruz. Técnica pecuaria en México, 44(2), 169-179. 